\title{
The Impact of Petroleum Prices on Inflation in Sri Lanka
}

\author{
W.T.K. Perera ${ }^{1}$
}

\begin{abstract}
This study attempts to measure the impact of changes in petroleum prices on inflation in Sri Lanka. The direct impact is measured through various components in the price indices that have a direct relationship with diesel prices. To measure the indirect impact of changes in petroleum prices on other items in consumer price indices, autoregressive distributed lag model was used. The results reveal that the indirect impact of changes in diesel prices on both Colombo Consumers' Price Index (CCPI) and Sri Lanka Consumers' Price Index (SLCPI) is much larger than the direct impact. Increase in diesel prices by 10 per cent would increase the monthly changes in CCPI by 1.21 per cent during the first month. In the case of SLCPI, the indirect impact of the same change in diesel price was 1.01 per cent with a lag of 2-3 months.

Result of co-integration tests reveal that two variables are not significantly co-integrated to form a long-run permanent relationship. These results imply that permitting domestic petroleum prices to adjust gradually rather than sharp adjustments within a short period could minimise the impact of large fluctuations in international prices on domestic price levels. (JEL L97, E31)
\end{abstract}

1/ Author wishes to gratefully acknowledge the excellent guidance by Dr. P.N.Weerasinghe, and also wishes to express her sincere thanks to Mr. K.D.Ranasinghe, Mr. C.J.P Siriwardene and Mr. K.L De Silva for their useful comments and suggestions. The author is however, solely responsible for any errors. 


\section{Introduction}

Factors affecting domestic inflation could broadly be divided into two categories, i.e., demand side and supply side factors that could arise domestically or externally. On the demand side, monetary policy, fiscal policy, wage policy and seasonal factors such as festivities affect inflation, while on the supply side, weather, cost of inputs, level of food production and changes in administered prices have an impact on inflation. Foreign prices and rupee depreciation are the main external factors affecting inflation. Rising oil prices, loose monetary and fiscal policies, upward revision of administered prices such as passenger transport fares and electricity tariff, fluctuation of domestic agriculture production, rupee depreciation and lagged impact of wage increases were the key factors that affected price levels in the recent past. This paper attempts to analyse the relationship between domestic inflation and petroleum prices.

Petroleum prices have a significant impact on the prices of goods and services as it is an essential intermediate good in the production process. In Sri Lanka, kerosene and diesel are the two major petroleum products that have an impact on prices. The demand for kerosene, which is largely being used for lighting purposes, has been on a declining trend along with rapid expansion of rural electrification. However, diesel is becoming the major petroleum product that is used in the production process including power generation, transportation and industries and therefore, strongly influences inflation. Of the total consumption of petroleum products, about 50 per cent is diesel, while petrol 10 per cent, kerosene 6 per cent and other products such as LP gas, furnace oil, and aviation fuel constitute the balance. Hence, the price of diesel can be considered as the most appropriate proxy to measure the impact of petroleum prices on consumer price levels.

The measurement of the impact of diesel price on domestic price levels is more crucial at present because domestic petroleum prices are expected to be determined according to world prices, exchange rate movements and other cost factors on the basis of a pricing formula, though it has remained suspended for a few months. With the opening of the petroleum market for competition, domestic petroleum prices are likely to change more frequently responding to market developments.

\section{A. Pricing Mechanism of Petroleum Products}

Until 2002, domestic prices of petroleum products were strickly administrated and for most of the time, were below the cost, even when the international prices were high. The difference between the domestic and world prices was absorbed by the government through direct or indirect subsidies. This prevented a direct impact on inflation but an indirect impact was felt through fiscal and monetary channels. Further, this situation created price distortions in the market. This policy was not sustainable as the burden of the subsidy on the government's budget became unbearable and Ceylon Petroleum Corporation's (CPC) exposure to the banking system exceeded prudential limits as subsidies were not granted in time. CPC's short term debt to the banking system increased to Rs. 23 bn. by end 2004, which was about 56 per cent of the total corporate credit. In general, every one dollar per barrel increase in international oil price leads to an increase the total cost of CPC by Rs.3 bn. Depreciation of the rupee against the US dollar also increases the cost of petroleum products. Every one rupee 
depreciation of the Rs./US\$ exchange rate would result in an increase of the total cost on petroleum products by Rs.1,300 mn. Under these circumstances, unless crude oil prices drop to very low levels, petroleum price administration become unrealistic and unsustainable.

Therefore, the government introduced a formula based automatic price adjustment mechanism to determine petroleum prices in the local market with a view to minimize the macroeconomic implications of petroleum pricing. The pricing formula is based on international average prices and other cost components and is compiled on a monthly basis. Formula based price adjustment was introduced from January 2002. However, the required price adjustments were not implemented in certain months on government directives.

With the introduction of this pricing mechanism, local consumer prices of petroleum products are expected to change with changes in international oil prices, exchange rate movements and other cost components. Under this pricing mechanism, the benefits of low international prices will be automatically passed on to the consumer, while when international prices are high, consumers will be called upon to bear the additional cost. With the expected more competitive market environment for petroleum products in the near future, domestic petroleum prices are expected to be determined in a more efficient and competitive manner.

Despite positive impact of new pricing system, policy makers face new challenges due to the frequent fluctuations of domestic petroleum prices, which is beyond their control. In particular, the price of diesel has a direct impact on transport fares, cost of power generation and indirectly on the prices of many consumer items in the basket used for computing price indices as well as on demand for higher wages.

In the backdrop of these developments, a clear understanding of the link between the price of diesel and consumer price levels is very important for policy makers to visualize inflationary impact of diesel price change, so that necessary policy actions could be derived to achieve price stability. A clear understanding of the impact of diesel prices on consumer price levels will be useful for monetary and fiscal policy implementation. Therefore, this study makes an attempt to quantify the direct and indirect impact of diesel prices on price levels based on presently available information. The direct impact can be measured easily by computing the share of petroleum inputs in individual components of the basket. However the measurement of indirect impact is not straightforward. An econometric technique is employed to measure the indirect impact of diesel prices on consumer price levels.
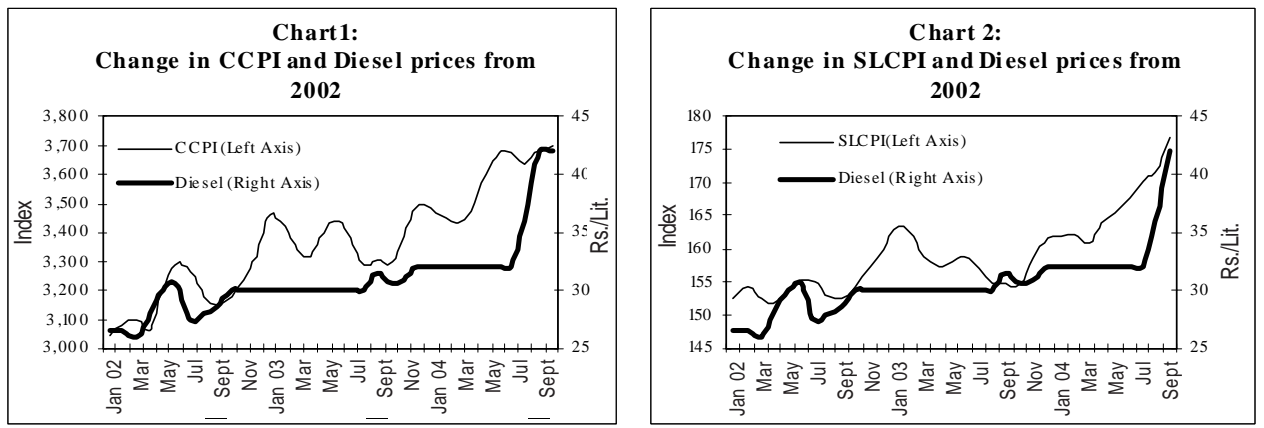


\section{B. Price Indices}

Colombo Consumers' Price Index (CCPI) (1952=100) computed by the Department of Census and Statistics (DCS), is the official consumer price index in Sri Lanka. Although there are similar price indices such as Colombo District Consumers' Price Index (CDCPI) and Greater Colombo Consumers' Price Index (GCPI), firms, households and government still form expectations of future prices based on the expected changes in the CCPI. The CCPI is used to determine the cost of living allowances payable to plantation workers and workers in other industries under the operation of the wages board ordinance. It is also widely used for wage adjustments in the private sector. Therefore, it is important to measure the impact of petroleum prices on CCPI.

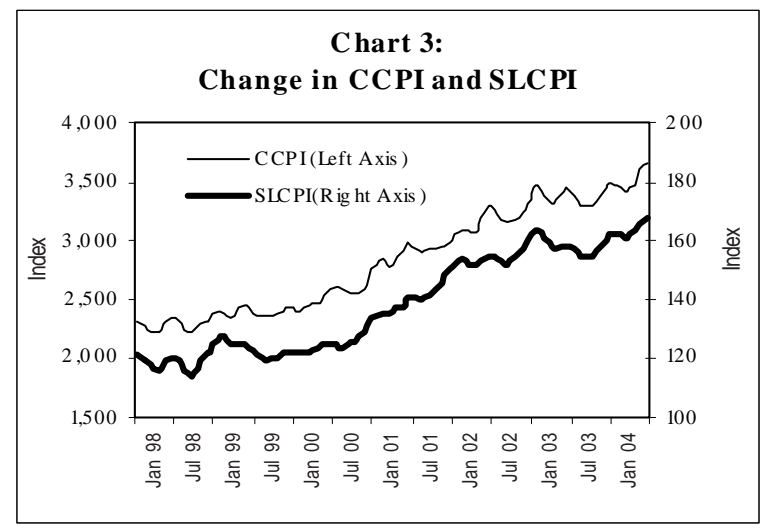

The consumer basket of the CCPI consists of 187 items, which is divided into five major components namely, food, clothing, fuel and light, rent and miscellaneous items. CCPI is over five decades old. A major drawback of this index is its outdated consumer basket. The prices are collected only from 7 centres in Colombo Municipality area. The Greater Colombo Consumers' Price Index (GCPI) (Jan. 1989 - June 1989 = 100) computed by the DCS covers a wider geographical area and is based on a more recent consumer basket. The Central Bank also compiles consumer price indices for the districts of Colombo, Matara, Anuradhapura and Matale.

In consideration of certain weaknesses in the price indices mentioned above, a new consumer price index namely, Sri Lanka Consumers' Price Index (SLCPI) $(1995-1997=100)$ has been introduced by the DCS. It covers the whole island excluding Northern and Eastern provinces. The consumer basket of the SLCPI consists of 174 items. SLCPI would become the official consumer price index in the future. Therefore, it is important to measure the impact of petroleum prices on SLCPI as well. However, there are limitations in measuring the indirect impact of Diesel prices on SLCPI, as data on SLCPI is available only from 1998. 


\section{Petroleum Prices}

Crude oil prices in the international market have increased rapidly over time. During the period January 1974 to December 2004, the highest crude oil price (Brent) in the international market was US\$52.13 per barrel in October 2004, while the lowest price of US\$9.17 recorded in December 1998. During the period June 1980 - Feb.1983, Oct. - Nov. 1990, Sep. - Nov. 2000, Jan. - March 2003 and Jan. - June 2004 crude oil prices remained over US\$30.00 per barrel. Further, it increased over US $\$ 40.00$ per barrel after July 2004. The average import price of crude oil by CPC was US $\$ 29.46$ per barrel in 2003 compared to US $\$ 25.17$ per barrel in 2002. It has risen to US\$37.72 per barrel in 2004.

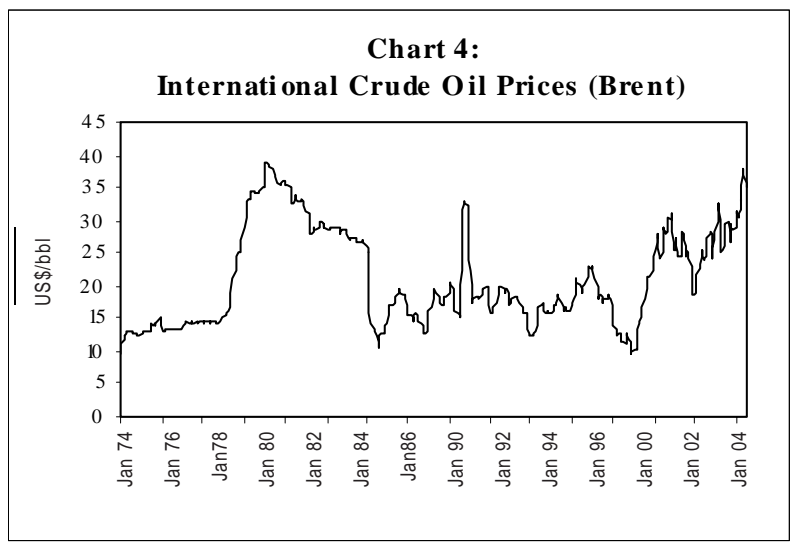

\section{Literature Review}

There are a few studies in the literature, which have examined the impact of change in petroleum prices on inflation. The major implications arising from the findings of these studies is that the oil price hike in the 1970's led to average price spiral and adverse macroeconomic consequences. However, these studies find that price volatility, particularly in the late 1990s have had insignificant impact on consumer prices. The major reason for the weaker inflation effect is that monetary policy implementation has been enforced particularly in developed countries so that monetary policy has not provided the basis for a sustained change in the inflation process.

The Blanc and Chinn (2004) estimate the effects of oil price changes on inflation for the United States, the United Kingdom, France, Germany and Japan using an augmented Phillips curve framework. Findings of this study suggest that oil price increases of as much as 10 percentage points will lead to direct inflationary increases of about $0.1-0.8$ percentage points in the US and some European countries. It also reveals that inflation in Europe, traditionally thought to be more sensitive to oil prices than in the US, does not show any significant difference in sensitivity from that in the US and in fact may be less in some European countries. 
Hooker (1999) estimates the effects of oil price changes on US inflation in a Phillips curve framework, allowing for some of the asymmetries, non-linearities and structural breaks that have been found in the literature on the real effects of oil price shocks. The paper finds strong evidence of a structural break with oil price changes making a substantial direct contribution to core inflation before 1980 but little or no pass-through since then. It has also been found that oil price effects on overall inflation are not significantly influenced and are consistent with their direct shares in price indices. Hooker (1999) attributes the results to the fact that monetary policy has become less accommodative of oil price shocks. Perhaps sufficiently so to prevent oil price changes from passing directly into inflation.

\section{Data and Limitations}

Monthly time series data for the period of January 1981 to June 2004 are used in the study. To measure the indirect impact of diesel prices on price indices, it is necessary to remove components in the indices that are directly related to diesel prices. These components are kerosene, electricity and transport prices in the CCPI. Therefore a modified index was used
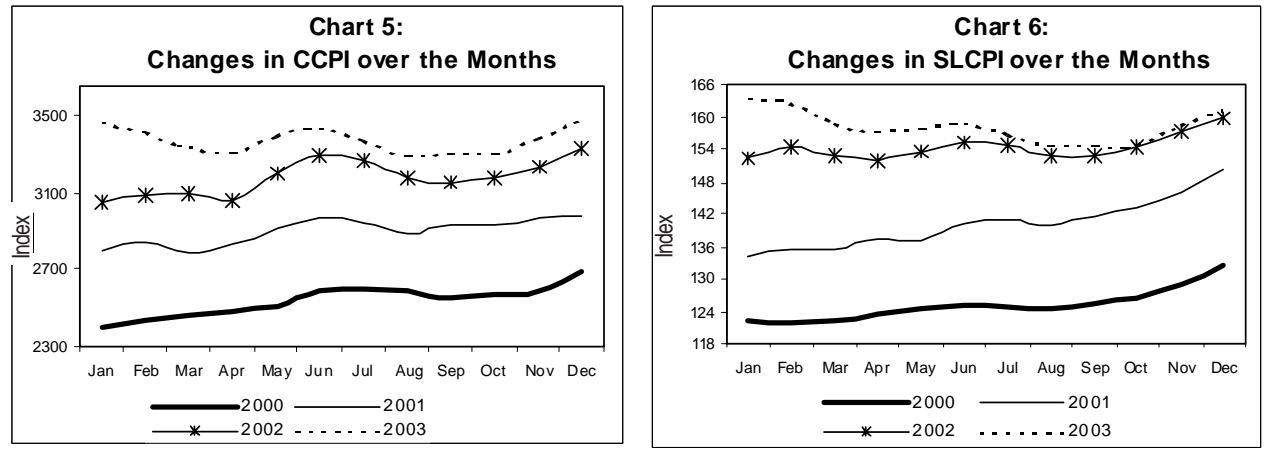

for the regression analysis. Similarly, SLCPI is also adjusted by excluding kerosene, electricity, gas and transport components in the index.

It has also been observed that there is a strong seasonal pattern in both CCPI and SLCPI as shown in chart 5 and chart 6 . Therefore, both price indices were deseasonalised before using in the regressions. Domestic diesel prices are used as a proxy for petroleum prices.

Data on CCPI and diesel prices are for the period of 1981:1 - 2004:6. As SLCPI is not available before 1998, data from 1998:1 - 2004:6 is used for SLCPI.

Before 2002 the diesel prices were strictly administered. Therefore, diesel prices were fairly stable during the period 1981 - 2001. But from 2002 it varied with the world market prices until September 2004, as diesel prices were subjected to monthly change.

\section{Model and the Methodology}

Direct impact can be measured easily by using the weights of the relevant components that directly affects price indices. 
To measure the indirect impact, an additional series of consumer price indices are constructed, excluding the direct impact of diesel prices. Econometric techniques are used to quantify the indirect impact of diesel prices on the CCPI and SLCPI.

Econometric analysis involves several steps. First, time series properties of data are examined using unit root tests. Second, based on time series properties of data, an appropriate regression model is developed to quantify the impact of changes in diesel prices on price indices. Finally, long run relationship between diesel prices and price indices is examined using co-integration technique.

\section{A. Test for Stationarity (unit root test)}

Before using time series data in econometric regressions, it is necessary to examine the statationarity of individual series of time series data as the use of non-stationary data in regression may sometimes produce misleading results through spurious relationships. Therefore, logarithms of all variables were tested for unit roots using Dickey Fuller (DF) test. DF tests based on the regression:

$$
\mathrm{Y}_{\mathrm{t}}=\rho \mathrm{Y}_{\mathrm{t}-1}+\mathrm{U}_{\mathrm{t}} \quad-1<=\rho<=1
$$

Where $\mathrm{U}_{\mathrm{t}}$ is a white noise error term.

if $\rho=1$; there exists a unit root, i.e., the variable is non-stationary.

Subtract $\mathrm{Y}_{\mathrm{t}-1}$ from both side of (1) to obtain:

$$
\begin{aligned}
Y_{t}-Y_{t-1} & =\rho Y_{t-1}-Y_{t-1}+U_{t} \\
& =(\rho-1) Y_{t-1}+U_{t}
\end{aligned}
$$

Which can be alternatively written as

$$
\Delta \mathrm{Y}_{\mathrm{t}}=\delta \mathrm{Y}_{\mathrm{t}-1}+\mathrm{U}_{\mathrm{t}}
$$

where $\delta=(\rho-1)$ and $\Delta$ is the first difference operator.

Unit roots can be tested by running the above regression. Hypothesis is given below.

Null hypothesis:

$$
\mathrm{H}_{\mathrm{O}}: \delta=0
$$

vs

Alternate hypothesis:

$$
\mathrm{H}_{1}: \delta \neq 0
$$

If $\delta=0$, then $\rho=1$, which implies that the series is non-stationary. If the series is nonstationary, the first difference of the series is tested for unit roots. If the series becomes stationary after first differencing, the first difference series can be used in OLS regression.

\section{B. Regression Model}

The following simple linear regression model is used to measure the relationship between consumer price level and diesel price. 


$$
\begin{aligned}
& Y_{t}= \beta_{1}+\beta_{2} X_{t}+U_{t} \\
& \text { Where } Y_{t}=\text { Seasonally adjusted price indices } \\
& X_{t}=\text { Price of diesel }
\end{aligned}
$$

If the natural logarithm values of the variables are used equation (4) transform as

$$
\operatorname{Ln} Y_{t}=\beta_{1}+\beta_{2} \operatorname{Ln} X_{t}+U_{t}
$$

Where $\operatorname{LnY}_{t}=$ Natural $\log$ value of $\mathrm{Y}_{\mathrm{t}}$

$$
\text { Ln } X_{t}=\text { Natural log value of } X_{t}
$$

If level variables are non-stationary, the model is transformed to a first difference model as given below:

$$
\begin{aligned}
\Delta \operatorname{LnY}_{\mathrm{t}}=\beta_{1}+\beta_{2} \Delta \operatorname{Ln~} \mathrm{X}_{\mathrm{t}} & +\mathrm{U}_{\mathrm{t}} \\
\text { Where } \Delta \operatorname{LnY} Y_{\mathrm{t}} & =\text { first difference of } \mathrm{LnY}_{\mathrm{t}} \\
\Delta \mathrm{Ln} \mathrm{X}_{\mathrm{t}} & =\text { first difference of } \operatorname{LnX}
\end{aligned}
$$

Since we want to get the relationship between $\mathrm{Y}_{\mathrm{t}}$ and $\mathrm{X}_{\mathrm{t}}$ we are going to check whether

$$
\begin{gathered}
\mathrm{H}_{\mathrm{O}}: \beta_{2}=0 \\
\text { vs } \\
\mathrm{H}_{1}: \beta_{2} \neq 0
\end{gathered}
$$

\section{Co-integration Test}

To check whether there is a long run relationship between these two variables, co-integration test is carried out for the level variables that have shown a statistically significant relationship.

All the variables that we used here are I(1). Suppose we regress :

$$
\begin{aligned}
Y_{t}= & \beta_{1}+\beta_{2} X_{t}+U_{t} \\
& \text { Where } Y_{t}=\log (\text { CEXKETSA }) / \log (\text { SLEXKEGTSA })
\end{aligned}
$$

CEXKETSA = Seasonal adjusted CCPI excluding Kerosene, Electricity and Transport. SLEXKEGTSA = Seasonal adjusted SLCPI excluding Kerosene, Electricity, Gas and Transport.

$$
\begin{aligned}
X_{t}= & \log (\text { diesel }) / \text { significant lag value of diesel price (i.e., } \log (\operatorname{diesel}(-1)), \\
& \log (\text { diesel }(-2)) \ldots . \quad \text { etc. })
\end{aligned}
$$


Write this as;

$$
\mathrm{U}_{\mathrm{t}}=\mathrm{Y}_{\mathrm{t}}-\beta_{1}-\beta_{2} \mathrm{X}_{\mathrm{t}}
$$

Check whether $\mathrm{U}_{\mathrm{t}}$ is stationary i.e., $\mathrm{I}(0)$. However, $\mathrm{Y}_{\mathrm{t}}$ and $\mathrm{X}_{\mathrm{t}}$ are individually $\mathrm{I}(1)$.

If $\mathrm{U}_{\mathrm{t}}$ is $\mathrm{I}(0)$, then we can conclude two variables are co-integrated, which means that these variables have a long-term relationship.

\section{The Analysis of Results}

\section{A. Direct Impact}

Weights of the CCPI and SLCPI are given in table 1 and table 2. The weights given for fuel reflect the direct impact on fuel prices on price indices.

Weights of components that are directly related to diesel prices are shown separately in the second column of the following tables. In the CCPI basket, share of those components is only 3.1 per cent. It is estimated that, in the component of transport cost of fuel is 27 per cent $^{2}$ of the total cost $(27 \%$ of $1.88 \%)$. Therefore, the total share of cost of diesel in this component in the CCPI basket has been estimated as 1.73 per cent.

With regard to SLCPI, kerosene, electricity, gas and petrol and other fuel prices have direct relationship with diesel prices. Total share of these items in the SLCPI basket is 2.6 per cent. Since electricity has about 0.7 per cent weight to the SLCPI basket the direct impact of

\section{Table 1: Weights in the CCPI basket}

\begin{tabular}{|l|cc|}
\hline \multicolumn{1}{|c|}{ CCPI (1952 =100) } & \multicolumn{2}{|c|}{ Weights } \\
\hline 1. Food & 61.89 & \\
2. Fuel \& Light & 4.29 & \\
$\quad$ Kerosene Oil & & 0.15 \\
$\quad$ Electricity & 5.70 & \\
3. Housing & 9.42 & \\
4. Clothing & 18.71 & \\
5. Miscellaneous & & 1.88 \\
$\quad$ Transport \& Travel & & \\
(Bus fare, other,petrol/ diesel) & 100.0 & 3.10 \\
\hline Total & & \\
\hline
\end{tabular}

Table 2: Weights in the SLCPI basket

\begin{tabular}{|l|cc|}
\hline \multicolumn{1}{|c|}{ SLCPI (1995-1997=100) } & Weights \\
\hline 1. Food, Beverages \& Tobacco & 71.2 & \\
2. Clothing \& Footwear & 4.0 & \\
3. Housing, Water,Electricity, & 13.1 & \\
$\quad$ Gas \& Other Fuels & & 1.0 \\
$\quad$ Kerosene Oil & & 0.7 \\
$\quad$ Electricity & & 0.2 \\
$\quad$ Gas & & \\
4. Furnishing, Household & 2.1 & \\
Equipment and Routine & 2.4 & \\
$\quad$ Maintenance of the house & 2.9 & \\
5. Health & & 0.7 \\
6. Transport $\quad 0.8$ & \\
$\quad$ Petrol \& Other Fuel & 1.3 & \\
7. Leisure, Entertainment and Culture & 0.8 \\
8. Education & 2.1 & \\
9. Miscelleneous Goods and Services & 100.0 & 2.6 \\
\hline Total & & \\
\hline
\end{tabular}

2/ Estimated in the report on formulation of a fares policy for bus transport services by the committee on Fares Policy, Ministry of Transport, Colombo. 
fuel prices to the electricity is considered as 10 per cent of the total cost (10\% of $0.7 \%)$. Therefore, the total share of cost of diesel in the SLCPI basket has been estimated as 1.97 per cent.

If diesel price increases by 10 per cent, the CCPI and SLCPI increase only by 0.173 per cent and 0.197 per cent ( $10 \%$ of $1.73 \%=0.173 \%$ and $10 \%$ of $1.97 \%=0.197 \%)$ respectively, assuming that prices of those items would also be adjusted immediately. It indicates that increase in diesel prices has only a very small direct impact on the indices.

\section{B. Indirect Impact}

Test for Stationarity (unit root test)

Before measuring the indirect impact using econometric techniques, all variables have been tested for stationarity, using the DF test. The results are reported below.

Table 3 : Results of the unit root test -Monthly data

\begin{tabular}{|c|c|c|c|c|c|c|c|c|}
\hline \multirow[b]{2}{*}{ Variable } & \multicolumn{2}{|c|}{ ADF Test Stat. } & \multicolumn{3}{|c|}{ C.V (Level) } & \multicolumn{3}{|c|}{ C.V (First Diff.) } \\
\hline & Level & First Diff. & $1 \%$ & $5 \%$ & $10 \%$ & $1 \%$ & $5 \%$ & $10 \%$ \\
\hline LOG(CEXKETSA) & -1.2454 & -6.7993 & -3.4556 & -2.8721 & -2.5723 & -3.4557 & -2.8721 & -2.5724 \\
\hline LOG(SLEXKEGTSA) & -0.1704 & -4.4563 & -3.5213 & -2.9012 & -2.5876 & -3.5239 & -2.9023 & -2.5882 \\
\hline LOG(DIESEL) & 0.4941 & -6.4235 & -3.4556 & -2.8721 & -2.5723 & -3.4557 & -2.8721 & -2.5724 \\
\hline
\end{tabular}

\section{Variable List}

$\log ($ CEXKETSA) = Natural logarithm of Seasonally adjusted CCPI (monthly) excluding Kerosene, Electricity and Transport.

$\log ($ SLEXKEGTSA $)=$ Natural logarithm of Seasonally adjusted SLCPI (monthly) excluding Kerosene, Electricity, Gas and Transport.

$\log ($ DIESEL $) \quad=$ Natural logarithm of Diesel prices

These results reveal that none of the variables are stationary in their levels. After first differencing all the variables became stationary. All the variables are stationary at 1 percent level of significance. Therefore, the order of integration is one (i.e., I(1) ) and therefore, the first difference variables are used in OLS regressions.

\section{Results of Regression}

Monthly data (seasonally adjusted)

Table 4 summarizes the results of regression that measures the impact of change in monthly diesel prices on the CCPI and SLCPI. The first two columns report the results of regression that has only the change in diesel prices as the explanatory variable. Since there could be some serial correlation in monthly data, the lagged dependent variable was added. These results are reported in the column (3) and (4) of Table 4. 
Table 4 : Regression Results - Monthly data

\begin{tabular}{|c|c|c|c|c|}
\hline \multirow[b]{3}{*}{ Independent Variable } & \multicolumn{4}{|c|}{ Dependent Variable } \\
\hline & \multicolumn{2}{|c|}{ With Serial correlation } & \multicolumn{2}{|c|}{ Without Serial correlation } \\
\hline & $\begin{array}{c}\text { DLOG } \\
\text { (CEXKETSA) } \\
\text { (1) }\end{array}$ & $\begin{array}{c}\text { DLOG } \\
\text { (SLEXKEGTSA) } \\
\text { (2) }\end{array}$ & $\begin{array}{c}\text { DLOG } \\
\text { (CEXKETSA) } \\
\text { (3) }\end{array}$ & $\begin{array}{c}\text { DLOG } \\
\text { (SLEXKEGTSA) } \\
\text { (4) }\end{array}$ \\
\hline DLOG(DIESEL) & $\begin{array}{l}0.080^{*} \\
(3.46)\end{array}$ & $\begin{array}{l}-0.006 \\
(-0.21)\end{array}$ & $\begin{array}{l}0.079^{*} \\
(3.47)\end{array}$ & $\begin{array}{l}-0.005 \\
(-0.187)\end{array}$ \\
\hline DLOG(DIESEL(-1)) & $\begin{array}{l}0.052^{* *} \\
(2.25)\end{array}$ & $\begin{array}{l}0.034 \\
(1.27)\end{array}$ & $\begin{array}{l}0.042^{* * *} \\
(1.77)\end{array}$ & $\begin{array}{l}0.034 \\
(1.26)\end{array}$ \\
\hline DLOG(DIESEL(-2)) & - & $\begin{array}{l}0.059^{* *} \\
(2.16)\end{array}$ & - & $\begin{array}{l}0.054^{* * \star} \\
(1.97)\end{array}$ \\
\hline DLOG(DIESEL(-3)) & - & $\begin{array}{l}0.054^{* *} \\
(2.00)\end{array}$ & - & $\begin{array}{l}0.047^{\star * *} \\
(1.70)\end{array}$ \\
\hline DLOG(CEXKETSA(-1) & - & - & $\begin{array}{l}0.135^{* *} \\
(2.29)\end{array}$ & - \\
\hline DLOG(SLEXKEGTSA(-1)) & - & - & - & $\begin{array}{c}0.105 \\
(0.917)\end{array}$ \\
\hline R2 & 0.056 & 0.116 & 0.074 & 0.124 \\
\hline DW Stat & 1.73 & 1.74 & 1.97 & 1.96 \\
\hline
\end{tabular}

Figures below coefficient in parenthesis represent $\mathrm{t}$ - ratios.

* - Significant at $1 \%$ level

** - Significant at $5 \%$ level

*** - Significant at $10 \%$ level

DLOG(CEXKETSA) = First difference of natural logarithm of Seasonal adjusted CCPI excluding Kerosene, Electricity and Transport.

DLOG(SLEXKEGTSA $)=$ First difference of natural logarithm of Seasonal adjusted SLCPI excluding Kerosene, Electricity, Gas and Transport.

In both regressions, changes in diesel prices are statistically significant in explaining the monthly changes in CCPI and SLCPI indices. In the case of CCPI, an increase in the diesel prices by 10 per cent would increase monthly change in CCPI by 0.79 per cent within the month. It also increases the following month's change in CCPI by 0.42 per cent. Therefore, the total impact of the increase in change in diesel prices by 10 per cent would be 1.21 percentage points of the CCPI which would be within the first two month of the price increase.

In the case of SLCPI, the indirect impact appears to be with a time lag. For example, an increase in the change in diesel price by 10 per cent would increase monthly changes in SLCPI by 0.54 per cent after two months and further increases the SLCPI by 0.47 after three months. Therefore, the total impact of the change would be 1.01 percentage points within three months.

The differences in the time lags between two indices could be explained by the different coverage of two indices. Since CCPI covers cost of living only in the Colombo city, indirect impact of any change in diesel price on the CCPI is likely to be quicker. The SLCPI covers almost the whole country, any change in diesel prices, is likely to affect items in the basket, particularly on food items, with a longer time lag. 
The above results can be used to visualise the impact of past changes in diesel prices on price indices. For this purpose, past CCPI and SLCPI indices have been computed after removing both direct and indirect impact of diesel price changes from January 2000. The results are given in Annex II and III. The following Charts shows comparable indices, point to point inflation and 12 months average inflation with and without diesel price changes.

\section{Colombo Consumers' Price Index}
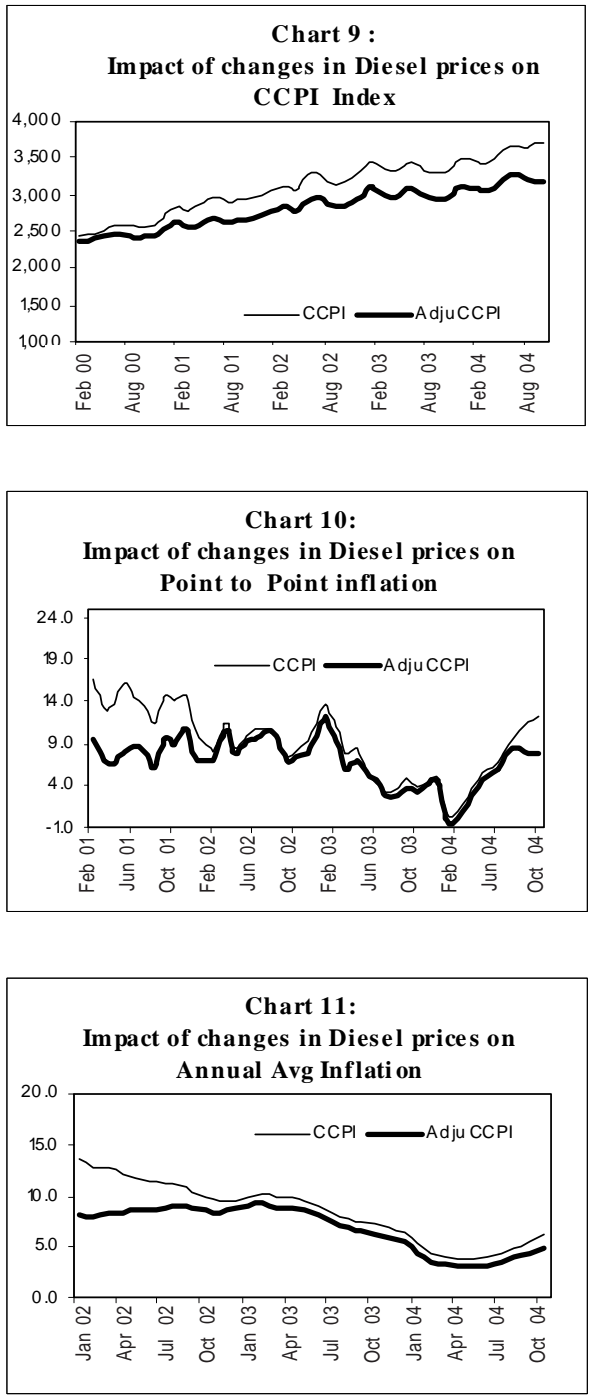

Sri Lanka Consumers' Price Index
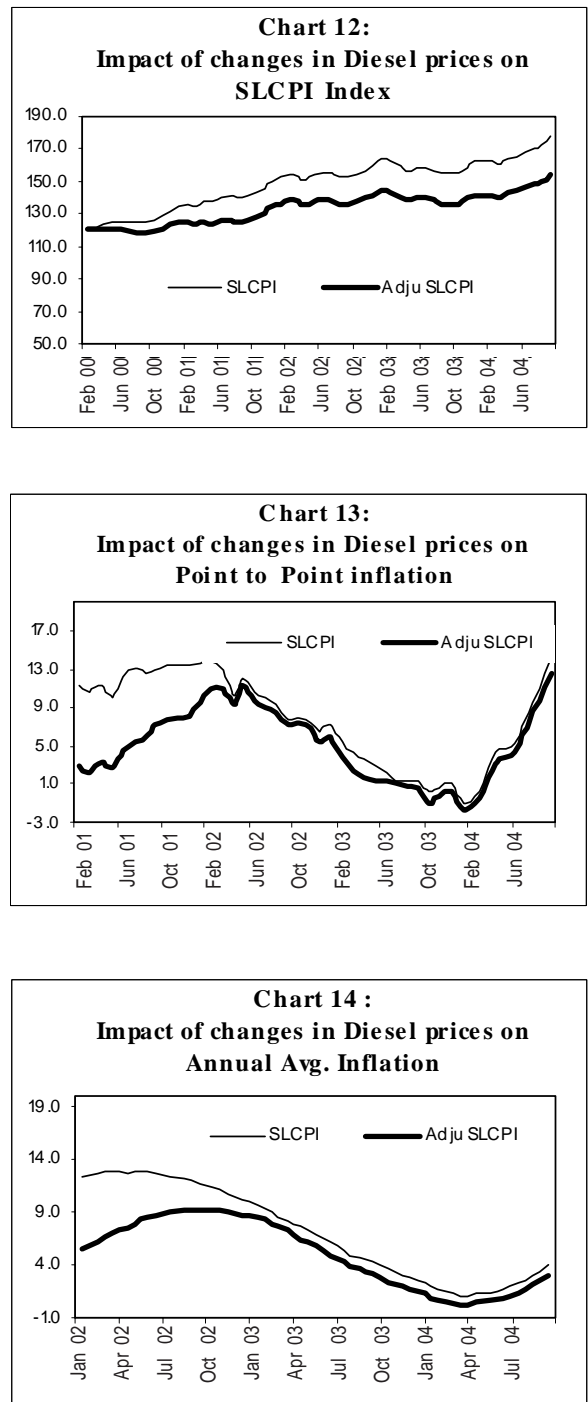

Note: Adju. CCPI /Adju SLCPI - CCPI / SLCPI excluding direct and indirect impact due to diesel price change. 
According to the computation, the impact of changes in diesel prices from January 2000 on CCPI is the increase of CCPI by 478 index points due to the indirect impact by October 2004. The direct impact would be another 55 index points. The total impact of changes in diesel prices on CCPI since 2000 is 533 index points. Accordingly, the indirect impact of changes in diesel prices is significantly higher than the direct impact as the share of components in the basket, with a direct impact, is only 1.73 per cent.

Based on the above computation, point to point inflation and 12 months moving average inflation have also been computed to assess the impact of changes in diesel prices on price indices from January 2000.

The sharpest increase in diesel prices was during 2000/2001 when diesel prices were increased by almost 90 per cent from Rs. 13.20 per litre in January 2000 to Rs. 24.50 in January 2001. The total impact of this change has increased point to point inflation in February 2001 by 7.3 percentage points to 16.6 per cent.

Change in diesel prices during 2000 and 2001 from Rs. 13.20 per litre to Rs. 27.50 by December 2001, has increased 12 months moving average inflation by 5.4 percentage points to 13.5 per cent in January 2002. This result implies that high inflation recorded during 2002 has been mainly due to change in petroleum prices during the previous period.

The impact of change in diesel prices on both point to point and average inflation has been around one percentage point during 2003 and until recently as price adjustments were gradual. The impact on point to point inflation is rising again since August 2004 with the recent sharp increases in diesel prices. This result implies that gradual adjustment of diesel prices could keep its impact on inflation to a minimum level of around one percentage point. Sharp adjustment would lead to significant increase in inflation in the short-term.

Same calculation has been done for the SLCPI. Accordingly, the impact of diesel prices from January 2000 on SLCPI is the increase of SLCPI by 20 index points due to indirect impact, while the direct impact would be another 3 index points, by September 2004. The impact of change in diesel prices during the year 2000/2001 on the point to point inflation would be an increase of 8.3 percentage points to 11.2 per cent. At the same time change in diesel prices have increased the 12 months moving average inflation in January 2002 by 6.8 percentage points to 12.4 per cent.

These results can also be useful to forecast the impact of change in diesel prices on future inflation.

\section{Results of the Co-integration Test}

A series of co-integration tests were carried out to examine whether there exists a long run relationship between diesel prices and price indices. Results are reported in table 5. Seasonally adjusted price indices were regressed against diesel prices and a few of its lags. The rationale to use lagged variables is that at first difference regressions, some lagged diesel prices had a significant relationship with prices. Stationarity of the residuals of these regressions were tested using ADF tests to ascertain whether there is a long run relationship between two variables in the regression. 
Table 5 : Results of the co-integration test

\begin{tabular}{lclll}
\hline Variable & ADF Stat. at Level & $\mathbf{1 \%}$ & $\mathbf{5 \%}$ & $\mathbf{1 0 \%}$ \\
\hline RCKDSA & -1.222 & -3.456 & -2.872 & -2.572 \\
RCKDSA1 & -1.224 & -3.456 & -2.872 & -2.572 \\
RSLKDSA & -1.304 & -3.521 & -2.901 & -2.588 \\
RSLKDSA2 & -1.400 & -3.521 & -2.901 & -2.588 \\
RSLKDSA3 & -1.455 & -3.521 & -2.901 & -2.588 \\
\hline
\end{tabular}

List of variable

Residuals of

Log(CEXKETSA) Vs Log(DIESEL) - RCKDSA

Log(CEXKETSA) Vs Log(DIESEL(-1)) -RCKDSA1

Log(SLEXKEGTSA) Vs Log(DIESEL) - RSLKDSA

Log(SLEXKEGTSA) Vs Log(DIESEL(-2)) - RSLKDSA2

Log(SLEXKEGTSA) Vs Log(DIESEL(-3)) - RSLKDSA3

Residuals of all regressions between several combinations of price indices and diesel prices were found to be non-stationary. This result implies that there is no long run relationship between diesel prices and consumer price levels.

\section{Conclusion}

This study measures the impact of petroleum prices on consumer prices. Price of diesel was used as a proxy for petroleum prices as diesel is widely used for transportation, power generation and has a direct relationship with consumer prices. The direct impact is measured through items relating to petroleum prices which are included in the price indices. For example, electricity charges and transport fares are directly linked to diesel prices. The study found that an increase in diesel prices by 10 per cent would directly increase CCPI and SLCPI by 0.173 per cent and 0.197 per cent, respectively.

To measure the indirect impact an autoregressive distributed lag model was used. Results reveal that the indirect impact of changes in diesel prices on both CCPI and SLCPI is much larger than the direct impact. Increase in diesel prices by 10 per cent would increase the monthly changes in CCPI by 1.21 per cent during the first month. In the case of SLCPI, the indirect impact of the same change in diesel price was 1.01 per cent with a lag of 2-3 months. Differences in the time lag affecting two indices could be explained by the differences in the geographical coverage of two indices.

These results show that sharp increases in point to point inflation in early 2001 and average inflation in early 2002 were largely due to sharp adjustment in diesel prices (a 86 per cent increase) during 2000. This implies that when diesel prices were adjusted gradually its impact on inflation was lower than that of a sharp adjustment within a short period. This finding also supports international evidence that countries with highly flexible domestic petroleum prices have been able to maintain low and stable inflation rates despite wide fluctuations in petroleum prices in international markets. Small and frequent adjustments could be easily absorbed into prices without causing high inflation. 
Co-integration test was used to examine whether there is a long-run permanent relationship between diesel prices and price indices. The result of co-integration reveals that two variables are not significantly co-integrated to form a long-run permanent relationship. The contradictory results between the short-term relationship and long-run relationship implies that although any shock to diesel prices would lead to a short-term impact on price levels, the relationship is not strong enough to form a long run relationship between the two variables. However, accumulation of several short-term shocks could have a significant impact on inflation, particularly when shocks are sharper as in 2000. This short-term impact of change in petroleum prices can be measured using the econometric techniques used in the study. The model could also be used to measure the impact of current changes in fuel prices on future inflation. 


\section{References}

Committee on Fares Policy, (2001), Report on formulation of a fares policy for bus transport services, August, Ministry of Transport, Colombo.

Energy Information Administration, (2001), Energy Price Impact on the U.S. Economy, April.

Hooker, Mark A., (1997), "Exploring the Robustness of the oil price - Macro economy Relationship" Federal Reserve Board, Stop 71, $20^{\text {th }} \&$ C St. October, NW, Washington DC, 20551.

Hooker, Mark A., (1999), “Are Oil Shocks Infationary? Asymmetric and Nonlinear specifications Versus Changes in Regime" Federal Reserve Board, Stop 71, $20^{\text {th }}$ \& C St. December , NW, Washington DC, 20551.

International Monetary Fund, (2000), “The Impact of Higher Oil Prices on the Global Economy”, December, Research Department, Washington D.C.

Karunathilake, H.N.S., (1974), "Inflation and the Sri Lanka Economy", Staff Studies, Vol. 4. No. 2, Central Bank of Sri Lanka, Colombo, pp185-197.

LeBlanc, Michael and Chinn, Minzie D., 2004, “ Do High Oil Prices Presage Inflation? The Evidence from G-5 Countries", Economic research service, U.S. Department of Agriculture.

Valadkhani, Abbas and Mitchel, William, "Assessing the Impact of Change in Petroleum prices on Inflation and Household Expenditures in Australia”, Centre for Full Employment and Equity, Department of Economics, The University of Newcastle, Australia. 


\section{Annex I}

\section{Variable List \\ Monthly Data}

$\begin{array}{ll}\text { CCPI } & =\text { Colombo Consumers' Price Index } \\ \text { CEXKET } & =\text { CCPI excluding kerosene, electricity and transport values } \\ \text { SLCPI } & =\text { Sri Lanka Consumers' Price Index } \\ \text { SLEXKEGT } & =\text { SLCPI excluding kerosene, electricity, gas and transport values } \\ \text { CCPISA } & =\text { Seasonally adjusted CEXKET } \\ \text { CEXKETSA } & =\text { Seasonally adjusted SLCPI } \\ \text { SLCPISA } & =\text { Seasonally adjusted SLEXKEGT } \\ \text { SLEXKEGTSA } & =\text { First difference of Log adjusted CCPI } \\ \text { DLog }(\text { CCPI }) & =\text { First difference of Log adjusted CEXKET } \\ \text { DLog }(\text { CEXKET) } & =\text { First difference of Log adjusted SLCPI } \\ \text { DLog }(\text { SLCPI }) & =\text { First difference of Log adjusted SLEXKEGT } \\ \text { DLog }(\text { SLEXKEGT) } & =\text { First difference of Log adjusted CCPISA } \\ \text { DLog }(\text { CCPISA) } & =\text { First difference of Log adjusted CEXKETSA } \\ \text { DLog }(\text { CEXKETSA) } & =\text { First difference of Log adjusted SLCPISA } \\ \text { DLog }(\text { SLCPISA) } & =\text { First difference of Log adjusted SLEXKEGTSA } \\ \text { DLog }(\text { SLEXKEGTSA) } & \text { First difference of Log adjusted diesel price } \\ \text { DLog }(\text { Diesel }) & =\text { Lag } 1 \text { of the first difference of Log adjusted diesel price } \\ \text { Dlog }(\text { Diesel (-1)) } & \end{array}$




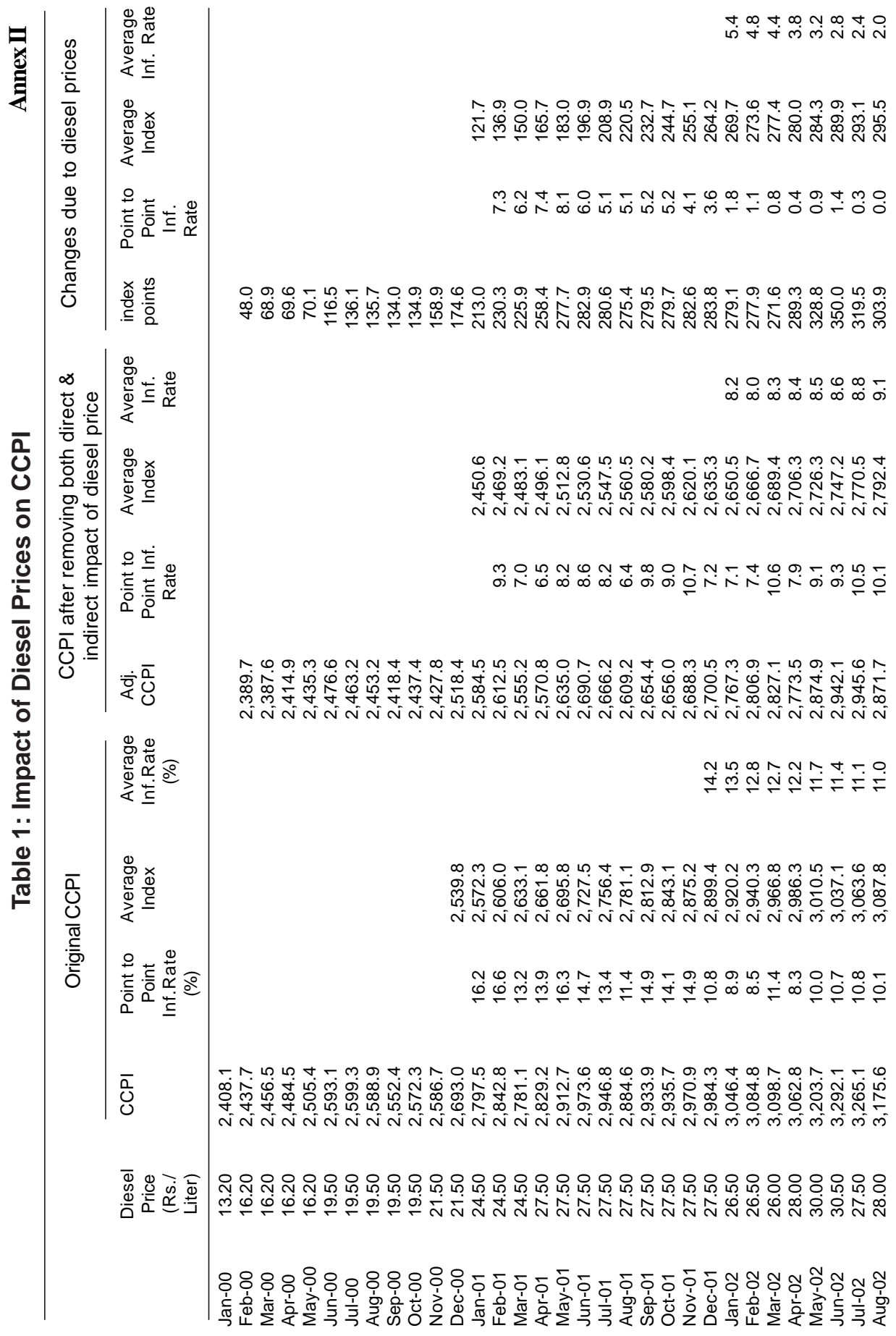




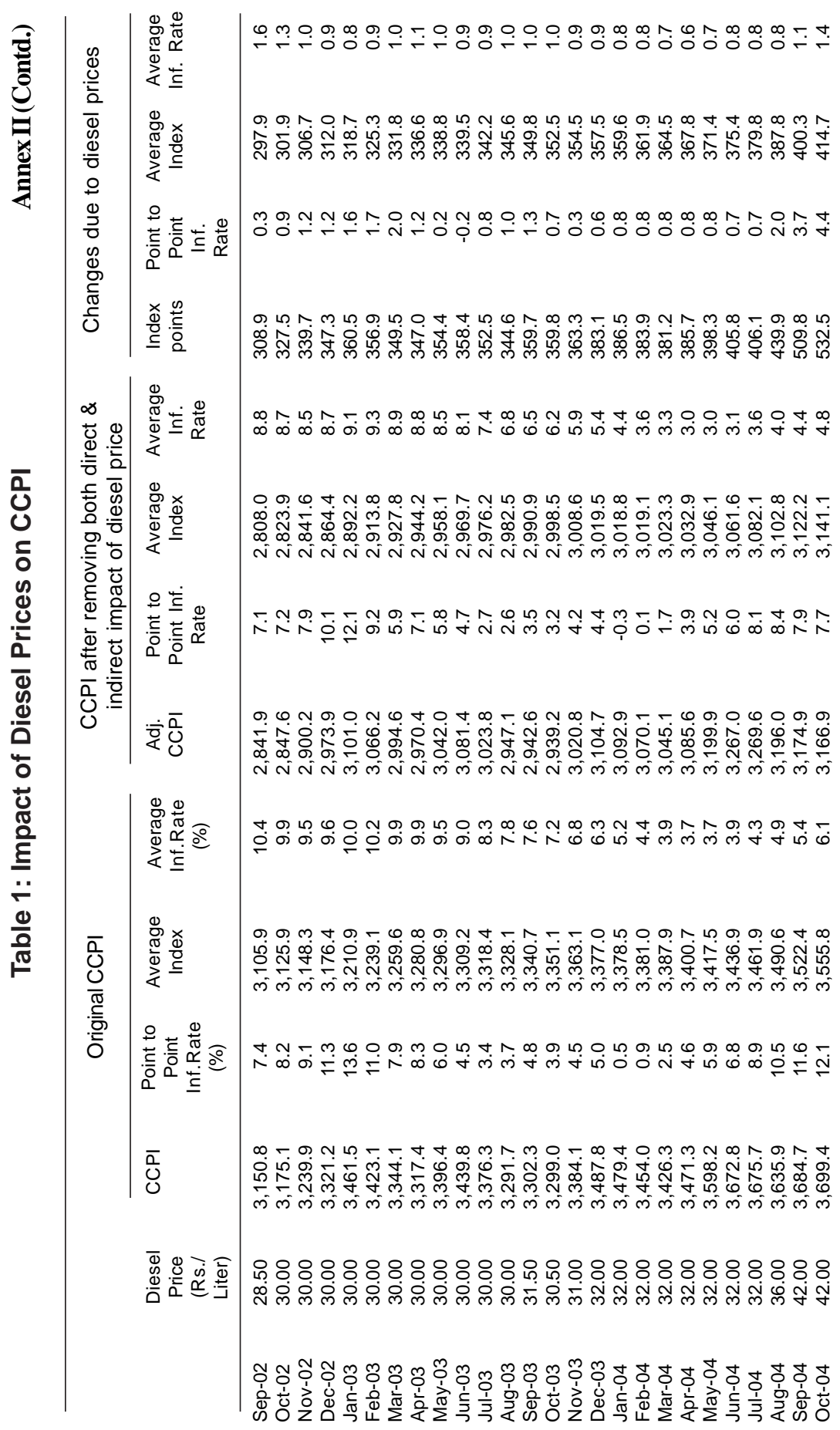




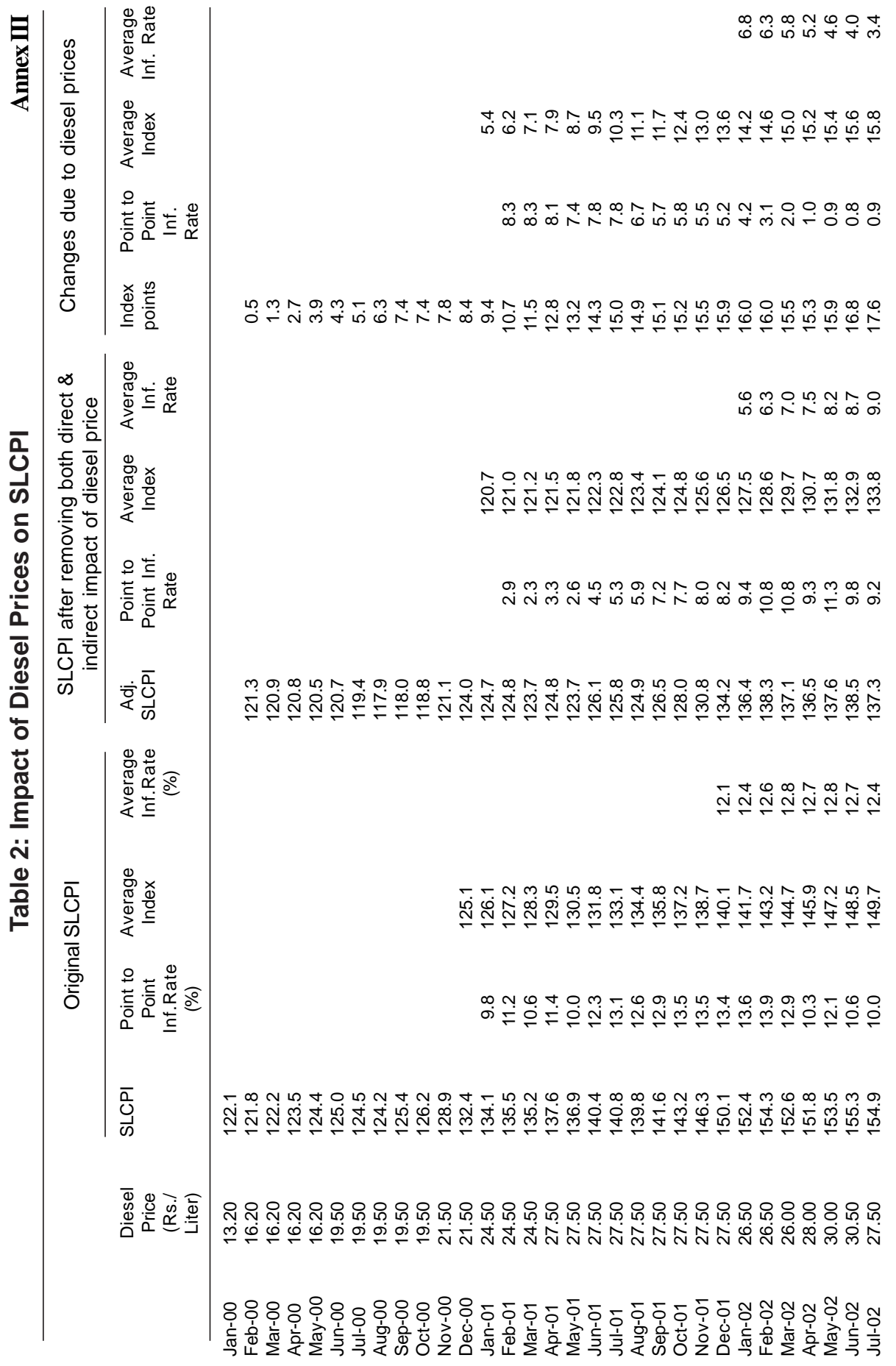




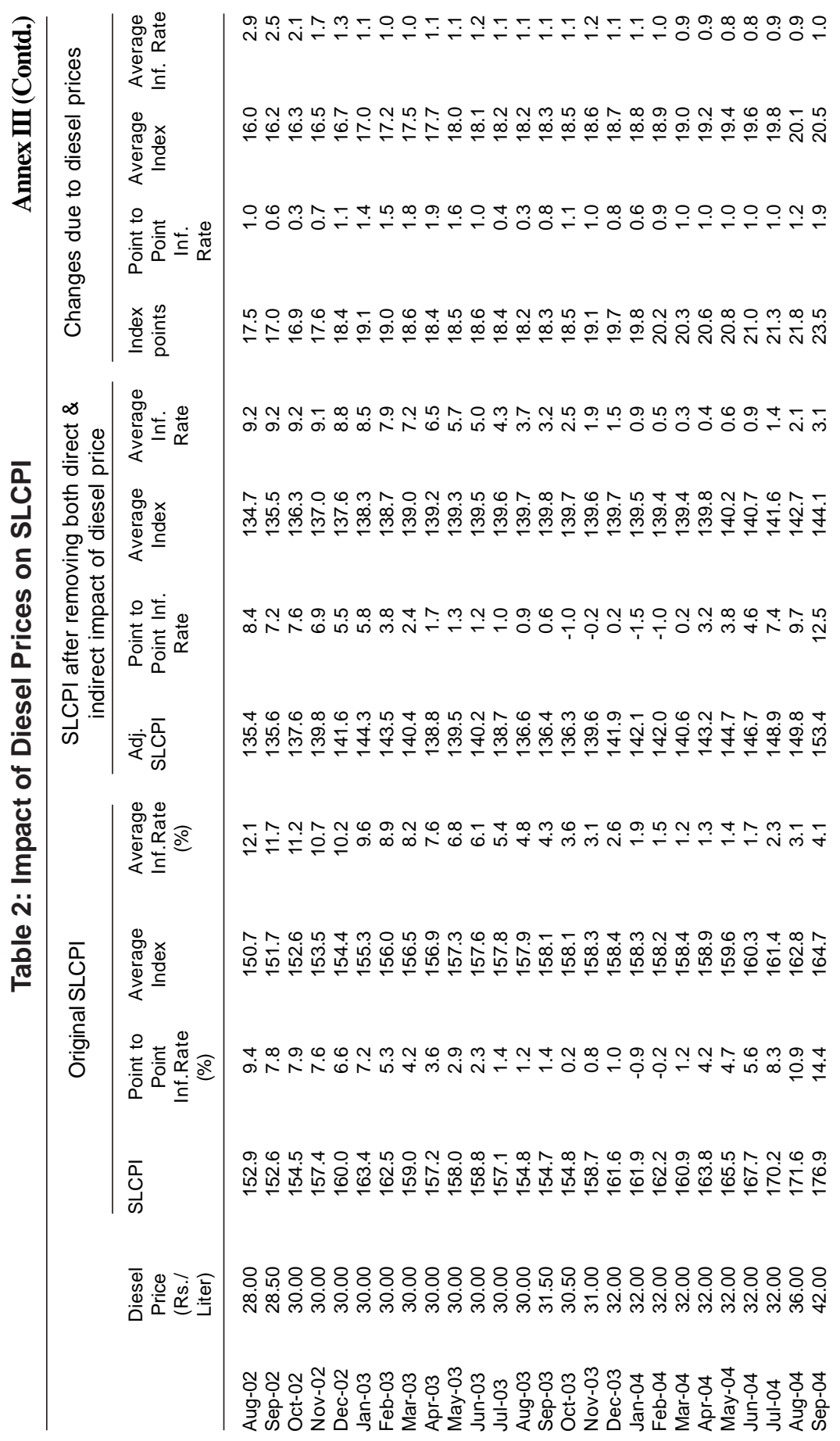

